\title{
青年期の自己評価と対人恐怖的心性との関連 ${ }^{1}$
}

\author{
東京都立大学 岡、田努・永井撤 ${ }^{2}$
}

Self-esteem and anthrophobic-tendency in adolescents

Tsutomu Okada and Thoru Nagai (Tokyo Metropolitan

University, Meguro-ku, Tokyo 152)

This study attempted to clarify the relationship between self-esteem and anthrophobic-tendency in normal adolescents. Two questionnaires measuring self-esteem and anthrophobic-tendency were administered to junior and senior high school students, and college students. The results show that for the junior high school and college students, self-esteem and anthrophobic-tendency correlated negatively, while there was an uncorrelativeness for the senior high school students. During senior high school age, they tend to estimate themselves in terms of their own standards rather than others', which result in little correlations between self-esteem and anthrophobictendency. The conflict between one's autistic tendency and interpersonal relations tends to lead to the anthrophobic-tendency.

Key words : self-esteem, anthrophobic-tendency, adolescence, standards, age-differences.

本研究は一般青年に和ける自己評価之対人恐怖的心性 の関連について, 青年期心性との関連から検討するもの である. 自己に対する評価（自己評価）之対人恐諦的傾 向との関連については, 臨床的な指摘が多くなされてい る反面，実証的に両者の関係を考察した研究は従来殆ど なされていない,よって本研究では, 質問紙上に現れた 自己評価及び対人恐怖的傾向について, 中学・高校・大 学生の各年代に和ける特徽を比較検討する。

対人恐怖的心性と自己評価との関係については，臨床 的研究からは幾つかの示唆的な報告がなされている。山 下(1977)によれば, 対人恐怖症者は自らの症状を“重大 な欠点”としてとら劣ていると述べられて物り，三好 (1970) に和いても，対人恐怖症者が現実の中で自尊心 をもって他者と関われない点を指摘して拉り，いずれる 自己評価と対人恐怖的心性の関連を強く示唆している. また実証的研究に和いても，井上（1981）が Janis \& Field (1959) の自尊感情に関する尺度の因子分析から, 自尊感情を構成する因子として“他者からの評価を気に する” “自己の価値観” “社会的場面に和壮る不安” “劣等 感”を挙げているが, これらは, 永井 (1987), 永井・岡 田 (1987) が一般青年に和ける対人恐怖的心性の特徽亡 して挙げたものと極めて類似したものとなっている。す なわち, 永井・岡田は対人恐怖的心性には, “対人状況 に晾沙行動の諸特徵（集団にとけこめない，対人場面 での気恥ずかしさ等)”“関係的自己意識（他者の評価や

1 本研究を進めるにまたり御指導・御校閲下さいまし た東京都立大学人文学部教授詫摩武俊先生に深く感謝い たします。

2 現所属 聖セシリア女子短期大学幼児教育学科。
視線が気になる)”“内省的自己意識（不安や劣等感が強 い)の3つの面が見られるとし，因子分析等の結果か らこの妥当性を確認している。

以上のように，対人恐怖的心性は青年期に和ける自己 概念の再構成に当たって自尊感情あるいは自己評価と深 く関わりをもつものであるといえる。よって本研究に和 いては, 対人恐怖的心性と自己評価との関係について, 青年期の中心的世代である中学・高校・大学の各世代間 について発達的に考察を行うものである。

$$
\text { 方法 }
$$

\section{調査対象}

東京都内の公立中学・公立高校・国公立大学生（主に 東京近郊の様々な高校出身の学生からなる）男女 1146 名について質問紙調查を行った. 内訳は，中学生が男子 218 名, 女子 188 名 ( 1 年生- 3 年生), 高校生が男子 223 名, 女子 245 名 ( 1 年生一 3 年生), 大学生が男子 211 名, 女子 61 名 ( 1 年生一 2 年生) である. 実施時 期は 1987 年 1 月から 3 月にかけてである。

\section{尺 度}

自己評価についての測定 Rosenberg (1965) の SelfEsteem Scale の邦訳版 (山本・松井・山成, 1982) を用 いる. 本尺度は個人の全体的な自己評洒の高さを測定す る目的で作成されたもので, 岡田 (1987) に拉いて中 学・高校・大学生に和ける尺度の 1 次元性が確認されて いる. 尺度は 7 件法 10 項目で, より得点の高い者程自 己評価が高いとされ，理論上とりらる得点の範囲は060 点である.

対人恐怖的心性についての測定 対人恐怖的心性の測 
Table 1

自己評価尺度及び対人関係尺度得点の平均と $S D(）$ 内及びその年代差

\begin{tabular}{|c|c|c|c|c|c|}
\hline 尺 度／年 代 & 学 & 校 & 大 & 年 & 式 差 \\
\hline 子 & $(n=218)$ & $(n=223)$ & $(n=211)$ & $F$ & 多重比較 \\
\hline 自己評 価 & $33.31 \quad(9.86)$ & $31.35 \quad(8.33)$ & $33.74 \quad(9.60)$ & 4. $10^{* *}$ & 高<中, 大 \\
\hline 対人状況に持ける行動の諸特徵 & $27.88(17.52)$ & $31.84(16.08)$ & $35.39(17.67)$ & $10.12^{* *}$ & 中<高<大 \\
\hline 関係的自己意識 & $29.37(17.55)$ & $35.15(16.08)$ & $35.99(15.41)$ & $10.27 * *$ & 中<高, 大 \\
\hline 内省的自己意識 & $31.38(17.21)$ & $36.68(15.27)$ & $35.21(14.44)$ & $6.69^{* *}$ & 中<高，大 \\
\hline 女 & $(n=188)$ & $(n=245)$ & $(n=61)$ & $F$ & 多重比較 \\
\hline 自己評 価 & $29.88 \quad(9.00)$ & $29.56 \quad(6.51)$ & $32.30 \quad(7.74)$ & $3.13^{*}$ & 中，高<大 \\
\hline 対人状況に打ける行動の諸特徴 & $25.56(16.73)$ & $30.95(15.36)$ & $33.31(15.75)$ & $8.40^{* *}$ & 中<高，大 \\
\hline 関係的自己意識 & $31.55(17.35)$ & $35.34(14.91)$ & $38.12(15.80)$ & $5.04^{* *}$ & 中<高, 大 \\
\hline 内省的自己意識 & $35.14(16.83)$ & $40.74(14.65)$ & $38.16(15.02)$ & $6.88^{* *}$ & 中, 大<高, 大 \\
\hline
\end{tabular}

Table 2

自己評価尺度と対人関係尺度各下位尺度との相関及び相関係数の年代差

\begin{tabular}{|c|c|c|c|c|}
\hline 尺 度/年 代 & 中 & 高 & 大 & 年 代 差 \\
\hline 子 & $(n=218)$ & $(n=223)$ & $(n=211)$ & $\chi^{2}(d f=2)$ \\
\hline 対人状沅に晾ける行動の諸特徵 & -.53 & -.13 & -.51 & $28.86^{* *}$ \\
\hline 関係的自己意識 & -.54 & -.06 & -.60 & $50.85^{* *}$ \\
\hline 内省的自己意識 & -.56 & -.17 & -.67 & $46.91 * *$ \\
\hline 子 & $(n=188)$ & $(n=245)$ & $(n=61)$ & $\chi^{2}(d f=2)$ \\
\hline 対人状況に和ける行動の諸特徴 & -.53 & -.25 & -.38 & $11.75^{* * *}$ \\
\hline 関係的自己意識 & -.53 & -.29 & -.47 & $9.28 * *$ \\
\hline 内省的自己意識 & -.62 & -.34 & -.69 & $20.09^{* *}$ \\
\hline
\end{tabular}

Table 3

自己評価得点の上位・下位群に郝ける対人関係尺度各下位尺度の平均と $S D$ ( ) 内

\begin{tabular}{|c|c|c|c|c|c|c|c|}
\hline \multirow{2}{*}{\multicolumn{2}{|c|}{ 尺 度/年 代 }} & \multicolumn{2}{|c|}{ 中 } & \multicolumn{2}{|c|}{ 高 } & \multicolumn{2}{|c|}{ 大 } \\
\hline & & $\mathrm{HI}$ & LW & $\mathrm{HI}$ & $\mathrm{LW}$ & $\mathrm{HI}$ & LW \\
\hline 男 & 子/n & 60 & 60 & 61 & 59 & 69 & 54 \\
\hline
\end{tabular}

対人状況に和ける行動

の諸特徵

関係的自己意識

内省的自己意識
$16.13(15.67) * * 37.92(16.94) \quad 27.34(18.92) n s 30.61(18.74) \quad 26.33(15.51) * * 49.24(16.35)$ 16. $70(14.04) * * 39.57(17.51) \quad 32.16(16.98) n s 33.44(19.22) \quad 25.73(12.06) * * 49.17(12.51)$ 18. $55(15.46) * * 41.68(17.27) \quad 32.48(15.39) n s 36.76(19.81) \quad 24.80(11.16)^{* * 47.78(12.12)}$

$\begin{array}{llllllll}\text { 女 } & \text { 子 } / n & 61 & 54 & 84 & 71 & 23 & 16\end{array}$

対人状況に和ける行動 の諸特徴

関係的状沇意識

内省的自己意識 $* * p<.01, \quad * p<.05$.

$13.90(11.45) * 36.50(16.33) \quad 28.44(15.63) n s 33.92(16.16) \quad 26.39(14.92) * 39.38(16.10)$ $20.08(12.76) * 43.98(16.50) \quad 33.12(15.84) n s 38.03(15.51) \quad 33.52(16.77) * 50.31(12.08)$ $22.54(12.78) * * 48.28(13.27) \quad 37.16(15.65) n s 45.89(14.28) \quad 30.70(10.85) * * 52.81(16.28)$

定に当たっては永井 (1987)，永井・岡田（1987）の対 人関係尺度 7 件法 42 項目を用いる. 本尺度は一般健常 者に括ける対人恐怖的心性を測定する目的で作成され たもので，“対人状況に郝子る行動の諸特徵”“関係的自 己意識”“内省的自己意識”のそれぞれ 14 項目からな
る3つの下位尺度から成り, その因子的妥当性が永井 (1987)，永井・岡田（1987）に衫いて確認されている. 各下位尺度ともより得点の高い者程対人恐怖的心性が高 いとされ，理論上とりらる得点の範囲は各下位尺度ごと に0-84 点である. 


\section{結果}

各尺度の尺度得点の平均と標準偏差, 及び男女別・各 年代間での分散分析の結果を Table 1 に示す (なお’, 多 重比較は Newman-Keuls の検定を用いた)。ここに見ら れるように，男女とも㸚人恐怖的傾向は年代とともに上 昇しているが，自己評価については，男子では高校生が 最も低く, 女子では大学生に和いて高くなっている. 自己評価得点と対人関係尺度各下位尺度得点の相関を Table 2 に示す. この相関係数の大きさの年代差を比較 するため, 相関係数を $z^{\prime}$ 変換した上で $\chi^{2}$ 検定を行っ た.この結果 Table 2 に見られるよらに，高校生に沶 いて有意に低い相関が見出された.

この結果をより明確にするため, 自己評価得点の上 位・下位各 $25 \%$ の者についての, 㸚人関係尺度各下位 尺度得点の平均と標準偏差を Table 3 に示した. 男女 別, 対人関係尺度各下位尺度別で自己評価得点の（上 位・下位群) $\times$ (年代) での $2 \times 3$ の分散分析を行ったと ころ，次のようになった。なわち“対人状況に和ける 行動の諸特徴”で男子 $F=12.57$ ( $p<.01$ : 上位群で中 学<大学, 高校, 下位群 で高校<中学<大学), 女子 $F=10.52(p<.01$ : 上位群 で中学<大学, 高校, 下位 群で有意差なし)，“関係的自己意識”で男子 $F=19.76$ $(p<.01)$ : 上位群で中学 $<大$ 学 $<$ 高校, 下位群で高校 $<$ 中学<大学), 女子では $F=13.02(p<.01$ ：上位群で中 学<高校, 大学, 下位群で高校<中学, 大学), “内省的 自己意識”では男子で $F=14.83$ ( $p<.01$ ：上位群で中 学<大学<高校, 下位群で高校, 中学<中学, 大学), 女子では $F=12.71(p<.01$ : 上位群で中学<大学<高 校，下位群で有意差なし）であった。また自己評価得点 上位・下位間の $t$ 検定の結果 Table 3 に見られるよう に, 高校生に扔いての及, 自己評価の上位群と下位群の 間に, 対人関係尺度得点の差はなく, 両群が他の年代に 比べ中間的な得点を得る形で近づいているとが見出さ れる。

\section{考察}

結果の章に招いて見られたように，対人恐怖的心性 は，年代が上昇するに伴って高くなる傾向が文られる. これは，年代の上昇に伴って自己に対する内省化が進 み，その結果他者と共にいるとき自分に過敏になる傾向 が著しくなると考学られる。自己評価については，男子 では高校生期に称いて低くなっており，一方女子では大 学生期に和ける自己評価が他に比べて高くなって拈り, 青年期に晾ける発達の性差を示唆するものである.Simmons, Rosenberg, \& Rosenberg (1973) は, 青年期に おいて自己評価が低下する傾向があるとして劦り，また 加藤（1977）も，高校生期に括いては自己批判的傾向が
高く自己受容性が低いとしており，男子に関する本研究 の結果は，これらと従来の研究に合致するものといえよ う，一方女子青年に和いては，女性として身体受容や性 同一性の確立が，自己評価と深くかかわっていることが 考えられ（松本・村上，1985；菅，1984），こうした女性 性について安定して受容できる，より後の年代ほど自己 評価が高くなることが考帛られる，ただし，大学生女子 についての調查対象の数が小さいため, 断定的な結論は 言壳ない。

自己評価と対人恐怖的心性の関係については，中学生 と大学生に括いては負の相関関係が久られ，従来の臨床 的研究を支持するものであるとい方よう。このことは, 青年期に和汀る自己意識との関連から，次のように考光 ることがでさる，青年期に和いては，客体自己と主体自 己の分化が大きくなり，その結果，自己覚醒 (Self-awareness) が高香ることが指摘されている (Rosenbereg, 1979）。自己覚醒が高皂った状態に括いて人は，現実の 自己の状態に対する知覚が鋭敏になり，自己のもつ“適 切さの基準 (standard)”，あるいは理想自己像との差が 意識されるために, 自己評価が低下し, これに伴ら不快 感から脱するため，基準に一致した行動をとるよう動 機つけられるといわれている (Duval \& Wicklund, 1972 ；押見，1986)。として，他者から見られる自己に注 意をより向けやすい, いわゆる公的自己意識の高い者ほ ぞ, 他者の評価や社会的規範などの自己の外的要因を基 準と乙て重視する傾向がある（押見，1986），菅原・山 本・松井 (1986) は自己意識特性の年齢的推移について の考察を行ったが，これによると青年期に䄧いては公的 自己意識が他の年代に比べ極めて高くなることが見出さ れている．菅原（1984） は公的自己意識と対人恐怖的傾 向の間に高い相関があることを指摘しているが，青年期 に拉ける自己評価との関係に関しては，次のように考兄 ることがでさよう.すなわち, 公的自己意識の高い青年期 に执いては，外的な基準に自己を一致させることで自己 評価を高く維持しようとする欲求が生じる反面，社会的 規範に対する反抗や，他者から安定して受容されるよう な関係が確立されていない（村瀬，1983）ことなどによ って，自己評価を高めることが困難な状況におかれる。 そして一般青年に和ける対人恐怖的心性の特徽として, 他者から見られる比較的肯定的な自己像に反して，現実 の自己像が理想像に比べ不完全であるという意識の葛藤 があげられる（木村，1983）ように，青年期においては 現実自己と理想自己のギャップをらめられないまま，す なわち低い自己評価のもとで対人恐怖的心性が生じやす くなると考えられるのである。

一方, 高校生に打いて，自己評価と対人恐怖的傾向と の間に負の相関関係が見られなかったことは，青年期心 性との関連に和いて非常に示唆的な結果であると考兄ら 
れる.これは，高校生期が大学受験等の激しい競争にさ らされる時期であり，他者との良好な関係によっては 自己を評価しにくくなるためと考えられる。また Blos (1962) が示唆するように，ごく一部の親友との関係を 除いて対他者関係から引きこもる傾向を示す時期である ことる関係しょう。すなわ，自己を評価するに際し て，他者からの評価を基準 (standards) にして自己を評 価する在り方よりも，自己の個人的属性によって評価す る在り方を，この時期の青年はとりやすく，よって対他 者関係に和ける困難さ，特にあまり親しくない者との間 での関係の困難を意味する対人恐怖的傾向が, 自己評価 との間に相関を持たなくなるのであろら。また大学生期 に招いては，自我同一性達成に関連して対人関係に招け る親密性が大きく関与してくる（近田, 1984) などのこ とから，自己に対する肯定的評価と対人関係が再び大き く関連するよらになると考学られ，自己評価と対人恐怖 的心性の相関がタられるようになるのであろう。

臨床的には，高校生期に伃いてのみ自己評価と対人恐 怖的心性の相関が見られなかったことは，この時期に抒 ける対人不適応に対する治療に示唆的な意味を持つと考 えられる。すなわら，一般に心理療法に扔いては個人の 自我の強さを高める自己評価を高めることで, 不適応の 改善をはかるが(菅, 1984)，この年代においては，そう したこと以上に，対人関係そのものを改善することす なわら環境調整が大きな意味を持つ可能性がある。

な扣，対人恐怖的心性のみならずその他の不適応的心 性や親子関係, 友人関係等他の変数と自己評価の関連 も，残された重要な課題であると考えられる.

\section{要約}

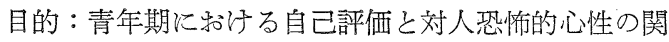
係についての発達的差異を考察する.

方法：自己評価及び対人恐怖的考察性に関する質問紙 調查を中学・高校・大学生男女 1146 名に対して実施する.

結果 : 中学生・大学生については自己評洒の高さと対 人恐怖的心性の間には負の相関関係が見られたが，高校 生に拉いては，高い相関関係は見られず，自己評価の高 得点群では他の年代に比べより高い対人恐怖的心性がみ られ，低得点群に括いてはより低い対人恐怖的心性が見 出された。

結論：中学・大学生期に括いては，自己を評価する基 準として他者からの評価を主に用いるのに対して, 高校 生期に执いては，他者との関係よりも自己自身に関心が 向き，青年自身の特性に基ついて自己を評価する傾向が 強いものと考えられる。

\section{引用 文 献}

Blos,P. 1962 On adolescence: A psychoanalytic interpretation. New York : Free Press.

近田輝行 1984 自我同一性之親密性一一後期青年期の 同輩集団と自己確立をめぐって——立教大学心理学 科研究年報, 26, 36-46.

Duval, S., \& Wicklund, R. A. 1972 A theory of objective self-awareness. New York: Academic Press.

井上祥治 1981 自尊感情の測定 遠藤辰雄(編) アイ デンティティの心理学 ナカニシヤ出版 Pp. 64-84.

Janis, I. L., \& Field, P.B. 1959 Sex differences and personality factors related to persuasibility. In C.I. Hovland \& I. L. Janis (Eds.), Personality and persuasibility. New Haven : Yale University Press. Pp. 55-68.

加藤隆勝 1977 青年期に括ける自己意識の構造 心理 学モノグラフ No. 14

木村法子 1983 青年期に和斿る対人恐怖的心性につい て—自己像との関連から—— 心理臨床学研究, 1, 7-17.

松本真理子・村上英治 1985 女子青年の性同一性に関 する研究—枠づけ面接法による接近の試み一一 心 理臨床学研究, 2 (2), 32-43.

三好郁男 1970 対人恐怖について——うぼれの精神 病理一精神医学, 12, 389-394.

村瀬孝雄 1983 青年の心理と対人恐怖 青年心理, 41, 673-682.

永井 撤 1987 対人恐怖的心性に関する心理学的研究 東京都立大学人文科学研究科博士論文 (未刊)

永井 撤・岡田 努 1987 対人恐怖的心性の構造に関 する研究 日本心理学会第51回大会発表論文集, 534 .

岡田 努 1987 青年期男子の自我理想と乞の形成過程 教育心理学研究, 35, 116-121.

押見輝男 1986 自己意識 対人行動学研究会(編) 対 人行動の心理学 誠信書房 Pp. 227-233.

Rosenberg, M. 1965 Society and the adolescent self-image. Princeton: Princeton University Press.

Rosenberg, M. 1979 Concerving the self. New York: Basic.

Simmons, R. G., Rosenberg, F., \& Rosenberg, M. 1973 Disturbance in the self-image at adolescence. American Sociological Review, 38, 553568.

菅 佐和子 1984 心理療法場面から見た女子青年の Self-Esteem の問題について 心理臨床学研究, 2 (1), 25-37.

菅原健介 1984 自己意識尺度（self-consciousness scale) 日本語版作成の試み心理学研究, 55, 184-188.

菅原 健介・山本真理子・松井豊 1986 Self-Consciousness の人口統計学的特徵 日本心理学会第 50 回大会発表論文集, 658 .

山本真理子・松井 豊・山成由紀子 1982 認知された 自己の諸側面の構造 教育心理学研究, 30, 64-68.

山下 格 1977 対人恐怖 金原出版 